\title{
HUBUNGAN ANTARA TINGKAT STRES KERJA DENGAN PEMILIHAN COPING STRESS STRATEGY KARYAWAN DI KANTOR PUSAT ADIRA INSURANCE
}

\author{
Johannes A. A. Rumeser; Theodora Elma Tambuwun \\ Jurusan Psikologi, Fakultas Psikologi, Bina Nusantara University \\ J1. Kemanggisan Ilir III No. 45, Kemanggisan, Palmerah, Jakarta Barat 11480
}

\begin{abstract}
Business development in Indonesia affects companies' competitiveness so they must be able to compete and survive to reach their goal. One of the ways is to use the resources well. Employees are one company resources that help to reach the goals, therefore they have a high possibility of having working stress in doing their job in the company. If employess have working stress, they will get ill and cause financial loss to company. This research is purposed to deal with working stress problems by investigate the relation between working stress level and choosing coping stress strategy for employees in Adira Insurance. Samples in this research consist of 30 men respondents, 49 women respondent, and 5 random respondents. This research type is nonexperimental, and as correlational research. This research founded that there is positive relationship between working stress level and choosing coping stress strategy for employees in Adira Insurance.
\end{abstract}

Keywords: working stress, coping stress, employees

\begin{abstract}
ABSTRAK
Berkembangnya bisnis di Indonesia mempengaruhi persaingan perusahaan sehingga harus mampu bersaing dan tetap bertahan untuk mencapai tujuannya. Salah satu caranya adalah dengan memanfaatkan sumber daya yang dimilikinya. Karyawan menjadi salah satu sumber daya perusahaan untuk mencapai tujuannya, karenanya mereka memiliki kemungkinan mengalami stres kerja ketika melakukan tugasnya di perusahaan. Stres kerja yang dialami karyawan menyebabkan karyawan tersebut jatuh sakit dan menyebabkan kerugian finansial bagi perusahaan. Penelitian ini bertujuan untuk mengatasi permasalahan yang ditimbulkan oleh stres kerja dengan menyelidiki hubungan antara tingkat stres kerja dan pemilihan coping stress strategy karyawan di Adira Insurance. Sampel dalam penelitian ini terdiri dari 30 responden pria, 49 responden wanita, dan 5 responden yang tidak mengisi data diri, dengan rentang usia antara 19-43 tahun, dan rata-rata usia 27,53 tahun. Jenis penelitian ini adalah Non-Experimental, dan merupakan penelitian korelasional. Penelitian ini menemukan adanya hubungan positif antara tingkat stres kerja dan pemilihan strategi coping stress karyawan di Adira Insurance.
\end{abstract}

Kata kunci: stres kerja, coping stress, karyawan 


\section{PENDAHULUAN}

Karyawan menjadi salah satu sumber daya perusahaan untuk mencapai tujuannya. Menurut Munandar (2001), manusia selaku unsur dinamis, melakukan proses kerja, misalnya mengolah materi/bahan baku dengan mesin dan metode yang dimiliki perusahan. Ketika melakukan proses kerja, karyawan berkemungkinan mengalami stres yang merupakan akibat atau hasil dari proses bekerja dalam perusahaan (Munandar, 2001). Stres yang dialami karyawan terdiri dari ketegangan, ketidaknyamanan, atau gejala fisik. Hal ini kita lihat sebagai stressor (pembangkit stres). Karyawan dipaksa untuk mengatasi stressor tersebut secara efektif (Lilienfeld, Lynn, Namy \& Woolf, 2009). Penelitian ini menggunakan pengertian stres yang dikemukakan oleh Lazarus \& Folkman (1984), yaitu stres terjadi saat terdapat ketidaksesuaian antara tuntutan lingkungan dan kemampuan seseorang.

\section{Stres}

Hidup yang berada dalam ketenangan dan kedamaian dalam waktu yang terlalu lama dapat menimbulkan rasa jemu. Rasa jemu yang berlebihan bisa menumbuhkan stres bagi seseorang (Atkinson, Atkinson \& Hilgard, 1991). Lazarus \& Folkman mendefinisikan stres berupa ketidaksesuaian antara tuntutan lingkungan dan kemampuan seseorang. Seseorang yang mengalami stres akan melakukan penilaian terhadap lingkungannya, melebihi kemampuan yang dimilikinya atau bahkan mengancam kesejahteraannya (Lazarus \& Folkman, 1984).

Penelitian mengenai stres di Amerika menemukan bahwa karyawan yang jatuh sakit kebanyakan diakibatkan oleh stres kerja. The National Institute for Occupational Safety and Health (NIOSH) menyimpulkan bahwa kondisi kerja memainkan peran utama dalam menyebabkan stres kerja (dalam Woolston, 2009). Hasil penelitian tersebut melaporkan bahwa stres kerja tidak hanya disebabkan oleh sifat pekerjaan itu sendiri, namun disebabkan juga oleh kecepatan kerja dan lingkungan, keamanan kerja, jam kerja, kesempatan untuk berkembang yang diperoleh karyawan, dan hubungan dengan atasan serta rekan kerja (dalam Woolston, 2009). Penelitian tersebut melaporkan $25 \%$ dari semua orang Amerika percaya bahwa pekerjaan mereka merupakan bagian yang paling stres dalam hidup mereka (dalam Woolston, 2009). NIOSH menyimpulkan bahwa penekanan lebih besar pada kondisi kerja sebagai sumber utama stres kerja (dalam Woolston, 2009). Berdasarkan penelitian diatas, peneliti ingin melihat sumber stres utama karyawan yang disebabkan oleh kondisi kerja.

Tidak hanya kondisi fisik karyawan, stres kerja yang dialami karyawan dapat mempengaruhi produktivitas karyawan. Menurut penelitian Warwick University, stres saat ini memiliki dampak yang lebih merusak pada produktivitas karyawan daripada kerusuhan industri yang terjadi pada tahun 1970 (dalam Woollard, 2009). Pusat Kesehatan Mental Sainsbury menunjukkan bahwa proporsi adanya penyakit yang dapat diatribusikan dengan kesehatan mental sebesar $44 \%$.

Sejalan dengan penelitian diatas, Woollard (2009) menjelaskan bahwa masalah stres dan hasil kesehatan mental yang terkait (seperti kecemasan, depresi, kecanduan, paksaan) tidak dipahami oleh perusahaan, bahkan dianggap tabu untuk dibahas. Masalah stress kerja yang dianggap tabu oleh perusahaan, menyebabkan kerugian perekonomian di Inggris. Perekonomian Inggris kehilangan 13.500.000 hari kerja setiap tahun karena stres di tempat kerja (dalam Knox, 2010). Di North East England diperkirakan terdapat 22.000 kasus stres kerja pada tahun 2008 (dalam Knox, 2010). Dapat disimpulkan bahwa stres bisa berdampak negatif bagi perusahaan dan kerugian finansial bagi negaranya.

Untuk mangantisipasi kerugian perusahaan dan kerugian finansial negara, diperlukan penanggulangan stres kerja. Menurut Woollard (2009), organisasi sebaiknya melakukan penilaian dan pemeriksaan mengenai stres yang dirasakan karyawan. 
Sejalan dengan pendapat Wollard, peneliti ingin melakukan penyelidikan mengenai stres yang dirasakan karyawan. Hasil penelitian sebelumnya menemukan hubungan antara tingkat stres kerja dan pemilihan coping stress strategy (Lazarus \& Folkman, 1984). Lazarus \& Folkman (1984) mengartikan coping stres sebagai usaha-usaha kognitif dan perilaku dinamis untuk mengelola tuntutan dari dalam dan/atau dari luar diri seseorang yang dirasakannya melebihi kemampuannya. Usaha kognitif yang dilakukan seseorang dalam menghadapi stres menunjukkan bahwa coping stress mampu dipelajari seseorang. Sejalan dengan pernyataan tersebut, hasil penelitian Primaldhi (2006) membuktikan metode coping stress bisa dipelajari oleh para karyawan dalam organisasi. Fokus penelitian ini yaitu melihat bagaimana hubungan tingkat stres kerja dan pemilihan coping stres strategy yang dilakukan pada karyawan di Kantor Pusat Adira Insurance.

\section{Stres Kerja}

Ross \& Altmaier (1994) mendefinisikan stres kerja berupa stres yang timbul akibat tekanan di tempat kerja. Menurut Ross \& Altmaier (1994), stres tersebut sebagai hasil interaksi kondisi karyawan dengan karakteristik masing-masing karyawan, dimana terdapat tuntutan karyawan yang berlebihan.

Definisi lain mengenai stres kerja, juga mengkaitkan individu dengan lingkungannya. Brousseau \& Prince mengartikan stres kerja sebagai suatu keadaan psikologis karyawan yang tidak menyenangkan untuk bekerja karena karyawan merasa terancam di lingkungan kerjanya (dalam Purwono, 2006). Begitu pula dengan pendapat Arsenault \& Dolan bahwa stres kerja merupakan kondisi psikologis yang tidak menyenangkan yang ditimbulkan karena karyawan merasa terancam, hal ini menunjukkan ketidaksesuaian antara individu dengan tuntutan pekerjaan (dalam Purwono, 2006). Shin juga mengartikan stres kerja sebagai kondisi lingkungan kerja yang bersifat negatif seperti konflik peran dan kurangnya kesempatan untuk berpartisipasi dalam pengambilan keputusan (dalam Purwono, 2006).

Sejalan dengan pernyataan diatas, masalah pekerjaan menjadi salah satu peristiwa yang membuat seseorang merasa stres. Holmes \& Rahe menyusun skala stres (social readjustment rating scale) dari peristiwa yang membuat seseorang merasa stres. Stres di tempat kerja menjadi bagian dalam SRRS (dalam Lilienfeld, Lynn, Namy \& Woolf, 2009).

Berdasarkan pernyataan di atas, dapat disimpulkan bahwa pekerjaan menjadi bagian dari peristiwa yang dapat menyebabkan individu mengalami stres. Peneliti ingin melihat tingkat stres kerja yang dialami karyawan di kantor pusat Adira Insurance. Peneliti berasumsi bahwa kantor pusat Adira Insurance merupakan perusahaan dengan tekanan kerja yang tinggi, dimana menurut Bass \& Barret (1981), persaingan bisnis merupakan salah satu stressor. Peneliti juga berasumsi bahwa tekanan kerja yang tinggi dikarenakan kantor pusat Adira Insurance bertanggung jawab mengontrol kegiatan kantorkantor cabang yang tersebar di beberapa wilayah Indonesia dan memiliki divisi usaha lebih dari satu. Untuk memastikan bahwa karyawan yang bekerja di kantor pusat Adira Insurance mengalami stres, peneliti akan mengukur tingkat stres kerja yang dialami karyawan di kantor pusat Adira Insurance.

\section{Sumber Stres Kerja}

Lazarus \& Folkman (1984) menyebutkan bahwa stres dipengaruhi oleh faktor tuntutan lingkungan. Sejalan dengan pendapat tersebut, Robbins \& Judge (2007) menemukan faktor-faktor yang menjadi penyebab stres seseorang. Semua faktor tersebut terdiri dari faktor lingkungan, organisasi dan pribadi. Robbins \& Judge (2007) menyebutkan bahwa sumber-sumber pada stres kerja bisa terjadi karena faktor lingkungan, organisasi dan pribadi.

Penelitian ini berfokus pada sumber stres yang disebabkan faktor organisasi. Faktor organisasi merupakan faktor-faktor di dalam suatu organisasi yang dapat mempengaruhi stres kerja karyawan. Terdapat tiga macam bentuk tuntutan yang termasuk dalam faktor organisasi, yaitu tuntutan tugas, 
tuntutan peran tuntutan interpersonal. Tuntutan tugas, misalnya otonomi, kondisi kerja, tata letak karyawan. Tuntutan peran merupakan ketidakcocokkan antara peran yang dijalankan dengan harapan karyawan yang menjalankan peran, kebingungan peran atau tidak diberitahu dengan pasti peran yang dijalaninya dalam perusahaan tersebut. Tuntutan yang terakhir yaitu tuntutan interpersonal. Tuntutan interpersonal diartikan hubungan sosial yang buruk dengan rekan kerja).

Penelitian ini berfokus pada faktor tuntutan tugas, tuntutan peran yang menempatkan karyawan pada peran tertentu di perusahaan dapat menyebabkan konflik peran yang sulit diselesaikan, dan tuntutan interpersonal. Peneliti membuat alat ukur dari teori teori sumber stres kerja yang dikemukakan oleh Robbins \& Judge (2007) yang digunakan sebagai informasi tambahan guna melihat sumber stres kerja yang terjadi di kantor pusat Adira Insurance.

\section{Gejala Stres Kerja}

Stres kerja yang dialami oleh karyawan memilliki gejala-gejala tertentu. Gejala-gejala dari stres tersebut ada yang tampak secara langsung dan tidak langsung, bahkan ada yang mempengaruhi kesehatan karyawan yang mengalami stres tersebut. Berikut ini penjelasan mengenai gejala-gejala stres kerja karyawan.

Penelitian ini menggunakan teori gejala stres kerja yang dikemukakan oleh Robbins \& Coulter (2007) yaitu gejala fisik, psikologis dan perilaku. Gejala pertama yaitu gejala fisik. Gejala fisik merupakan perubahan metabolisme tubuh, tekanan darah tinggi, sakit kepala, dan berpotensi mengalami serangan jantung. Selanjutnya, terdapat gejala psikologis. Gejala psikologis berupa ketidakpuasan kerja yang dirasakan karyawan, misalnya karyawan merasa tertekan, cemas, cepat marah, bosan, sehingga menunda pekerjaannya. Gejala terakhir yaitu gejala perilaku. Gejala perilaku digambarkan sebagai perubahan produktivitas, perubahan pola makan, gelisah, peningkatan penggunaan alkohol dan rokok, dan gangguan tidur.

Berdasarkan penjelasan di atas, dapat disimpulkan bahwa gejala stres dapat mempengaruhi kondisi fisik, psikologis, dan perilaku karyawan yang mengalami stres. Penelitian ini berfokus pada gejala stres yang mempengaruhi perilaku karyawan yang mengalami stres di tempat kerja.

\section{Dampak Stres Kerja}

Stres kerja juga bisa berdampak baik dan buruk. Selye membedakan distress sebagai stres yang mengarahkan pada kondisi negatif dan eustress sebagai kekuatan postif untuk mengarahkan pada hasil kerja yang baik (dalam Munandar, 2001). Penelitian ini berfokus pada stres yang mengarahkan seseorang pada kondisi negatif (distress). Kondisi negatif akibat stres kerja tidak hanya mempengaruhi kondisi psikis karyawan, namun kondisi fisiknya juga ikut dipengaruhi (Bass \& Barret, 1981). Sejalan dengan pernyataan tersebut, di Jepang tercatat 12 chief executive officer (CEO) meninggal dan kebanyakan disebabkan oleh beberapa stressor, seperti budaya karyawan di Jepang yang perfectionis, workaholic, persaingan bisnis dan kebiasaan makan yang buruk (dalam Dubrin, 1990). Tidak hanya para chief executive officer yang memperoleh dampak psikis yang negatif, penelitian lain melaporkan bahwa karyawan pada level staff dan first-level supervisors juga dapat mengalami stres (Bass dan Gerald, 1981). Stres yang mereka alami menyebabkan mereka dua kali lebih rentan terkena penyakit jantung dibandingkan para top level pada perusahaan (Bass dan Gerald, 1981). Berdasarkan penelitian diatas, dapat disimpulkan bahwa karyawan dari level manapun berkemungkinan mengalami stres yang mempengaruhi kondisi fisiknya.

Kondisi fisik dan psikis karyawan dapat mempengaruhi kondisi perusahaan. Penelitian Blix, Cruise, Mitchell \& Blix menyebutkan menurunnya produktivitas kerja karyawan dan ketidakhadiran karyawan berkaitan dengan stres (dalam Primaldhi, 2006). Kerugian akibat stres yang dialami Karyawan juga dialami di Inggris, perekonomian Inggris kehilangan 13.500 .000 hari kerja setiap 
tahun karena stres di tempat kerja (dalam Knox, 2009). Di North East England diperkirakan terdapat 22.000 kasus stres kerja pada tahun 2008 (dalam Knox, 2009).

Penelitian lain juga menemukan adanya dampak stres pada kondisi kesehatan karyawan. Berdasarkan penelitian Warwick University, stres saat ini memiliki dampak yang sangat merusak produktivitas karyawan (dalam Woollard, 2009). Penyakit yang diderita karyawan 44\% disebabkan masalah yang berhubungan dengan kondisi psikis karyawan (dalam Woollard, 2009). Menurut Woollard (2009), organisasi sebaiknya melakukan penilaian sifat dan skala dari masalah yang menyebabkan ketidaknyamanan kerja, melakukan pemeriksaan stres atau menggabungkan penilaian dalam survei tahunan karyawan. Berdasarkan berbagai penelitian diatas, dapat disimpulkan bahwa stres bisa berdampak negatif bagi karyawan dan kerugian bagi perusahaan. Maka dari itu, diperlukan penanggulangan stres kerja untuk menghindari kerugian tersebut. Sebagai langkah awal penanggulangan stres kerja, perlu diadakan penyelidikkan mengenai stres kerja. Berikut ini akan dibahas lebih lanjut mengenai coping stress.

\section{Coping Stress}

Usaha kognitif dan tindakan untuk mengelola tuntutan dari luar dan/atau dalam diri individu yang merugikan inilah yang disebut coping stress oleh Lazarus \& Folkman (1984). Menurut Aldwin (dalam Primaldhi, 2006), manusia tidak hanya menerima tuntutan dari lingkungan secara pasif buktinya adalah manusia melakukan coping.

Sejalan dengan pernyataan di atas, Lilienfeld, Lynn, Namy, dan Woolf (2009) mengemukakan bahwa individu secara aktif dapat menghilangkan stres dengan mengontrol situasi. Terdapat berbagai macam kontrol situasi stres. Menurut Lilienfeld, Lynn, Namy, \& Woolf (2009) terdapat lima macam, yaitu : behavioral control, cognitive control, decisional control, informational control, dan emotional control. Dari kelima jenis kontrol situasi stres diatas, peneliti ingin melihat kontrol stres berupa behavioral control dan cognitive control. Pada behavioral control terdapat strategi coping stress yaitu problem-focused coping dan pada cognitive control strategi coping stress yaitu emotion-focused coping. Fokus penelitian ini pada strategi coping berupa problem-focused coping dan emotion-focused coping.

Besarnya penggunaan problem-focused coping dan emotion-focused coping berbeda antara pria dan wanita. Penelitian di Australia oleh Patton \& Goddard (2006) menemukan perbedaan penggunaan strategi coping stress antara pria dan wanita. Penelitian Ptacek dan Skues \& Kirby (1995) (dalam Patton \& Goddard, 2006) melaporkan bahwa pria lebih menggunakan problem-focused coping dibandingkan wanita dalam menghadapi stres (dalam Patton \& Goddard, 2006). Sedangkan, karyawan wanita lebih menggunakan emotion-focused coping dibandingkan pria dalam menghadapi stres.

Selain melihat penggunaan problem-focused coping dan emotion-focused coping, penelitian ini juga menggunakan strategi coping yang lain, yaitu religious-focused coping. Religious-focused coping telah dikembangkan di Indonesia oleh Dahlan (dalam Primaldhi, 2006). Berikut ini akan dibahas lebih lanjut definisi mengenai problem-focused coping dan emotion-focused coping dan religious-focused coping.

Menurut Lazarus \& Folkman (1984), problem-focused coping berupa tindakan yang ditunjukkan individu untuk menimbulkan perubahan fisik, mental dan sosial terhadap hal yang menimbulkan stres. Lazarus \& Folkman (1984) menggambarkan problem-focused coping mirip dengan strategi yang digunakan seseorang dalam memecahkan masalahnya.

Strategi problem-focused coping erat kaitannya dengan tugas-tugas yang dapat dilakukan untuk menyelesaikan masalah (Lazarus \& Folkman, 1984). Lazarus \& Folkman (1984) memberikan 
sebuah contoh dalam konteks mahasiswa yang akan menempuh ujian.Jika ia mengalami stres dan menggunakan problem-focused coping, ia akan menyiapkan materi-,materi ujian, menyiapkan diri dan mengalokasikan waktu untuk belajar (Lazarus \& Folkman, 1984). Strategi problem-focused coping dilakukan seseorang ketika memiliki tingkat stres kerja tertentu. Lazarus \& Folkman (1984) juga menyebutkan bahwa seseorang melakukan problem-focused coping jika ia menilai situasi yang dialaminya bisa diubah atau ia merasa situasi tersebut memiliki tingkat ancaman sedang. Strategi coping stress yang akan diteliti berikutnya adalah emotion-focused coping. Menurut Lazarus \& Folkman (1984), strategi ini dilakukan individu jika ia menilai tidak ada yang bisa diperbuatnya pada situasi yang dihadapinya atau ia memberi nilai situasi tersebut sebagai situasi yang mengancam dengan tingkat tinggi.

Berdasarkan teori stres dan coping Lazarus \& Folkman (1984) serta Vitaliano, Russo, Carr, Maiuro \& Becker (dalam Primaldhi, 2006) mengelompokkan emotion-focused coping menjadi tiga kelompok, self-blame, avoidance, dan wishful thinking. Ketiga macam bagian emotion-focused coping diwakilkan dengan permyataan yang berbeda. Self-blame pada emotion-focused coping diwakilkan dengan salah satu pernyataan yaitu menyalahkan diri sendiri sebagai penyebab masalah (dalam Primaldhi, 2006). Berbeda dengan avoidance pada emotion-focused coping. Avoidance pada emotionfocused coping diwakilkan dengan salah satu pernyataan yaitu tidak percaya bahwa hal tersebut benarbenar telah terjadi (dalam Primaldhi, 2006). Bagian emotion-focused coping yang terakhir yaitu wishful thinking. Wishful thinking diwakilkan dengan salah satu pernyataan yaitu mengharapkan agar saya dapat mengubah apa yang terjadi (dalam Primaldhi, 2006).

Ketiga macam bagian emotion-focused coping tersebut telah disusun menjadi sebuah alat ukur bernama Ways of Coping (dalam Primaldhi, 2006). Susunan pernyataan yang mewakili emotionfocused coping pada alat ukur Ways of Coping akan dibahas lebih lanjut pada bab selanjutnya. Berikut ini akan dibahas mengenai teori religious-focused coping yang digunakan pada penelitian ini.

Strategi coping terakhir yang digunakan dalam penelitian ini adalah religious-focused coping yang dikembangkan oleh Dahlan (dalam Primaldhi, 2006) di Indonesia. Menurut Pergament (1997), religious-focused coping merupakan suatu bentuk usaha menghadapi masalah yang dihadapi dengan melakukan ritual keagamaan, seperti berdoa, ke tempat ibadah, atau berdoa. Primaldhi (2006) menyimpulkan bahwa strategi coping ini didasari oleh adanya keyakinan bahwa Tuhan akan membantu seseorang yang mempunyai masalah.

Penelitian yang dilakukan oleh Pergament (1997) menunjukkan bahwa ketika menghadapi situasi yang stresful seperti kematian, penyakit, perceraian atau perpisahan dengan pasangan karena masalah hukum, atau situasi apapun yang dinilai negatif, kebanyakan partisipan penelitian melibatkan agama untuk mengatasi berbagai masalahnya.

Dahlan (dalam Primaldhi, 2006) membagi bentuk religious-focused coping menjadi dua bagian, yaitu religious belief dan religious behavior. Dahlan (dalam Primaldhi, 2006) menemukan bahwa religious-focused coping selalu dilakukan oleh subyek orang Indonesia, ketika mereka menghadapi stressor tertentu (dalam Primaldhi, 2006). Oleh karena itu, penelitian ini juga menggunakan religious-focused sebagai salah satu jenis coping yang berkemungkinan dipilih oleh sampel, karena sampel penelitian ini merupakan orang Indonesia. Penelitian ini hanya berfokus pada religious-focused coping dalam bentuk religious belief.

Pada penelitian di Indonesia, Dahlan (dalam Primaldhi, 2006) menemukan adanya hubungan antara religious-focused coping dengan strategi problem-focused coping, dan emotion-focused coping, pada sampel Indonesia. Analisis tambahan pada penelitian ini juga melihat hubungan dari ketiga strategi coping stress. Dari jenis coping yang telah dijelaskan sebelumnya, selain pada problemfocused coping dan emotion-focused coping, penelitian ini juga berfokus pada religious-focused coping. Jadi, penelitian ini ingin melihat pemilihan strategi coping stres yang terdiri dari problem- 
focused coping, emotion-focused coping, dan religious-focused coping ketika karyawan mengalami stres kerja.

\section{Hubungan Tingkat Stres Kerja dengan Pemilihan Strategi Coping Stress}

Lazarus \& Folkman (1984) mengemukakan bahwa penggunaan problem-focused coping dan emotion-focused coping bergantung pada tingkat stres yang dirasakan seseorang. Lazarus \& Folkman (1984) menyebutkan bahwa individu melakukan problem-focused coping jika ia menilai situasi yang dialaminya bisa diubah atau ia merasa situasi tersebut memiliki tingkat ancaman sedang. Berbeda dengan penggunaan strategi emotion-focused coping, strategi ini dilakukan individu jika ia menilai tidak ada yang bisa diperbuatnya pada situasi yang dihadapinya atau ia memberi nilai situasi tersebut sebagai situasi yang mengancam dengan tingkat tinggi (Lazarus \& Folkman, 1984). Pada tingkat stres tinggi, seseorang akan lebih menggunakan emotion-coping stress (Lazarus \& Folkman, 1984).

Berdasarkan pernyataan diatas, dapat disimpulkan bahwa pada tingkat stres rendah, seseorang akan menggunakan problem-focused coping dan emotion-focused coping dengan frekuensi yang sama. Pada tingkat stres menengah, seseorang akan lebih menggunakan problem-focused coping (Lazarus \& Folkman, 1984). Pada tingkat stres tinggi, seseorang akan menggunakan emotion-focused coping (Lazarus \& Folkman, 1984). Penelitian ini berfokus pada hubungan antara tingkat stres kerja dengan strategi pemilihan coping stress yang dialami karyawan di kantor pusat Adira Insurance.

\section{Hipotesis}

Hipotesis pertama yaitu bahwa terdapat hubungan positif antara tingkat stres kerja dengan penggunaan strategi emotion-focused coping, artinya semakin tinggi tingkat stres kerja, maka semakin sering penggunaan emotion-focused coping. Hal ini ditandai dengan meningkatnya nilai penggunaan emotion-focused coping, sejalan dengan semakin tinggi tingkat stres kerja yang dialami karyawan. Hipotesis kedua yaitu bahwa terdapat hubungan negatif antara tingkat stres kerja dengan penggunaan strategi emotion-focused coping, artinya semakin tinggi tingkat stres kerja, maka semakin rendah penggunaan emotion-focused coping. Hal ini ditandai dengan menurunnya nilai penggunaan emotionfocused coping, sejalan dengan semakin tinggi tingkat stres kerja yang dialami karyawan.

\section{METODE}

\section{Responden}

Populasi penelitian ini adalah karyawan yang bekerja di kantor pusat Adira Insurance, yaitu sebanyak 345 karyawan. Peneliti tidak menggunakan semua karyawan di kantor pusat Adira Insurance. Dari total 120 kuesioner yang dibagikan peneliti, hanya 84 kuesioner yang diisi dan dikembalikan. Responden penelitian ini terdiri dari 30 responden pria (35,7\% dari total responden), 49 responden wanita (58,3\% dari total responden) dan 5 responden yang tidak mengisi data diri $(6 \%$ dari total responden). Rentangan usia responden antara 19-43 tahun. Rata-rata usia responden yaitu 27,53 tahun. Sebagian besar responden pada penelitian ini menganut agama Islam, yaitu sebanyak 63 orang ( $75 \%$ dari total responden). Selanjutnya, terdapat 7 orang beragama Kristen Protestan (8,3\%dari total responden), diikuti dengan 5 orang beragama Kristen Katolik (6,0\% dari total responden), dan 2 orang beragama Hindu (2,4\% dari total responden), serta sebanyak 7 orang tidak menjawab $(8,3 \%$ dari total responden). Berdasarkan pendidikan terakhir, responden penelitian ini terbagi menjadi lima kelompok. Sebagian besar responden penelitian ini berpendidikan terakhir D4/S1, yaitu sebanyak 56 orang responden. Pada urutan kedua, terdapat responden dengan pendidikan terakhir D3 sebanyak 12 orang (14,3 \% dari total responden). Pada urutan ketiga, terdapat responden dengan pendidikan terakhir S2 sebanyak 6 orang $(7,1 \%$ dari total responden), selanjutnya terdapat responden dengan pendidikan SMA/SMK sebanyak 1 orang (1,2\% dari total responden), dan responden dengan pendidikan terakhir 
D1 sebanyak 1 orang (1,2\% dari total responden), serta 8 orang tidak menjawab (9,5\% dari total responden).

Responden pada penelitian ini terbagi menjadi 11 kelompok berdasarkan divisi perusahaan. Divisi Dealer, Leasing, and Agency sebanyak 12 karyawan (14,3\% dari total responden), SMEC and Micro Banking sebanyak 9 karyawan (10,7\% dari total responden), Corporate Business sebanyak 5 karyawan (6,0 \% dari total responden), Business Devt. sebanyak 12 karyawan (14,3\% dari total responden), Claim and Technical Operation sebanyak 3 karyawan (3,6\% dari total responden), Finance and Accounting sebanyak 10 karyawan (11,9\% dari total responden), National Operation sebanyak 8 karyawan (9,5\% dari total responden), HCD and GA sebanyak 6 karyawan (7,1\% dari total responden), IT sebanyak 4 karyawan (4,8 \% dari total responden), Corporate Planning sebanyak 7 karyawan $(8,3 \%$ dari total responden), dan responden yang tidak menjawab sebanyak 8 karyawan (9,5\% dari total responden). Gambaran responden berikutnya dapat dilihat dari jenjang karir di Adira Insurance. Jenjang karir di Adira Insurance terdiri dari karyawan magang/free lance, admin, officer, associate/analyst, department head, division head, dan direktur. Pada tabel 4.6, tampak bahwa responden yang paling banyak yaitu associate/analyst sebanyak 32 orang $(38,1 \%)$, diikuti dengan officer sebanyak 23 orang (27,4\%), admin sebanyak 12 orang (14,3\%), department head sebanyak 4 orang $(4,8 \%)$, magang/free lance sebanyak 4 orang $(4,8 \%)$, division head sebanyak 1 orang $(1,2 \%)$, dan subjek yang tidak menjawab sebanyak 8 orang $(9,5 \%)$.

\section{Pengukuran}

\section{Stres Kerja}

Tingkat stres kerja karyawan diukur dengan kuesioner Personal Stress Inventory yang telah diterjemahkan dan diuji realibilitas serta validitasnya oleh Dahlan (dalam Primaldhi, 2006). Pada pilot study dengan subjek 32 karyawan perusahaan lain, kuesioner Personal Stress Inventory menunjukkan realibilitas $(\partial=0.84)$.

Personal Stress Inventory terdiri dari 41 item pernyataan, namun berdasarkan saran atau expert judgement, peneliti menggunakan short form dari kuesioner Personal Stress Inventory. Short form tersebut terdiri dari 15 pernyataan dan memiliki realibilitas Alpha Cronbach sebesar $\partial=0.715$. Kuesioner Personal Stress Inventory menggunakan skala likert 1-5. Skala 1 mewakili jawaban "tidak pernah saya rasakan/lakukan". Skala 2 mewakili jawaban "sekali-sekali (ada kalanya) saya rasakan/lakukan". Skala 3 mewakili jawaban "agak sering saya rasakan/lakukan". Skala 4 mewakili jawaban "sangat sering saya rasakan/lakukan". Skala 5 mewakili jawaban "selalu saya rasakan/lakukan".

Pada Personal Stress Inventory terdapat kategorisasi tingkat stres kerja. Kategorisasi tingkat stres kerja tersebut dibuat setelah responden mengisi Personal Stress Inventory. Peneliti mencari nilai rata-rata dari keseluruhan jawaban responden. Responden yang memiliki tingkat stres kerja di atas rata-rata keseluruhan responden dinyatakan sebagai responden dengan tingkat stres kerja tinggi. Responden yang memiliki tingkat stres kerja di bawah rata-rata keseluruhan responden dinyatakan sebagai responden dengan tingkat stres kerja rendah.

\section{Coping Stress Strategy}

Diukur dengan menggunakan Kuesioner Ways of Coping Checklist. Kuesioner Ways of Coping Checklist terdiri dari problem-focused coping dan emotion-focused coping, serta teori yang dikemukakan oleh Pergament (1997) dan Dahlan (dalam Primaldhi, 2006) yaitu religious-focused coping. Dahlan telah melakukan pengujian reliabilitas dan validitas pada kuesioner Ways of Coping Checklist. Masing-masing item dari tiap-tiap strategi coping stress telah diuji reliabilitas dan 
validitasnya, item problem-focused coping $(\partial=.81)$, item emotion-focused coping $(\partial=.81)$ dan item religious-focused coping dan telah diuji realibilitasnya $(\partial=.91)$ oleh Dahlan (dalam Primaldhi, 2006).

Kuesioner Ways of Coping Checklist terdiri dari 55 pernyataan yang terdiri dari 21 pernyataan yang mewakili problem-focused coping, 21 pernyataan yang mewakili emotion-focused coping, dan 13 pernyataan yang mewakili religious-focused coping.

Kuesioner Ways of Coping Checklist menggunakan skala likert 1-5. Skala 1 mewakili jawaban "tidak relevan untuk dilakukan dalam mengatasi situasi stres yang saya hadapi". Skala 2 mewakili jawaban "relevan, tapi tidak saya lakukan dalam mengatasi situasi stres yang saya hadapi". Skala 3 mewakili jawaban "jarang saya lakukan dalam mengatasi situasi stres yang saya hadapi". Skala 4 mewakili jawaban "sering saya lakukan dalam mengatasi situasi stres yang saya hadapi". Skala 5 mewakili jawaban "selalu saya lakukan dalam mengatasi situasi stres yang saya hadapi".

Setelah melakukan pilot study, peneliti hanya menggunakan short form dari kuesioner Ways of Coping Checklist. Short form tersebut dinilai telah mewakili pernyataan lainnya. Short form pada kuesioner tersebut terdiri dari 6 pernyataan yang mewakili problem-focused coping, 12 pernyataan yang mewakili emotion-focused coping, dan 5 pernyataan yang mewakili religious-focused coping. Reliabilitas Alpha Cronbach kuesioner Ways of Coping Checklist pada pilot study sebesar $\partial=.814$.

\section{Sumber Stres Kerja}

Penelitian ini mengukur sumber stres kerja karyawan berdasarkan teori yang dikemukakan oleh Robbins \& Judge (2007). Robbins \& Judge (2007) menyebutkan tiga hal yang termasuk dalam sumber stres kerja karyawan, yaitu: tuntutan tugas (otonomi, kondisi kerja, tata letak karyawanan, dan lainnya), tuntutan peran yang menempatkan karyawan pada peran tertentu di perusahaan dapat menyebabkan konflik peran yang sulit diselesaikan, dan tuntutan interpersonal yang terjadi dengan rekan kerja (hubungan sosial yang buruk dengan rekan kerja).

Peneliti membuat kuesioner sumber stres kerja karyawan. Peneliti menggunakan 17 item pernyataan yang terdiri dari 5 pernyataan yang mewakili dimensi tuntutan tugas, 6 pernyataan yang mewakili dimensi tuntutan peran, dan 6 pernyataan yang mewakili tuntutan interpersonal.

Kuesioner Sumber Stres Kerja menggunakan skala likert 1-5. Skala 1 mewakili jawaban "tidak pernah saya rasakan/lakukan". Skala 2 mewakili jawaban "sekali-sekali (ada kalanya) saya rasakan/lakukan". Skala 3 mewakili jawaban "agak sering saya rasakan/lakukan". Skala 4 mewakili jawaban "sangat sering saya rasakan/lakukan". Skala 5 mewakili jawaban "selalu saya rasakan/lakukan".

Peneliti menguji realibilitas Kuesioner Sumber Stres Kerja dengan menggunakan penghitungan Alpha Cronbach pada SPSS. Peneliti mendapatkan realibilitas Alpha Cronbach sebesar $\partial=.86$. Realibilitas Alpha Cronbach item-item tuntutan tugas sebesar $\partial=.794$, realibilitas Alpha Cronbach item-item tuntutan peran sebesar $\partial=.756$, dan realibilitas Alpha Cronbach item-item tuntutan interpersonal sebesar $\partial=.718$.

\section{Analisis}

Analisis utama pada penelitian ini yang akan diuji adalah dengan menguji hubungan antara tingkat stres kerja dan coping stress strategy, problem-focused coping, emotion-focused coping, dan religious-focused coping menggunakan korelasi Pearson. Analisis tambahan menggunakan independent sample T-Test untuk mengetahui ada atau tidaknya perbedaan rata-rata antara dua kelompok sampel yang tidak memiliki hubungan (dalam Priyatno, 2008). Peneliti juga menggunakan 
analisis oneway ANOVA untuk mengetahui ada atau tidaknya perbedaan rata-rata pada lebih dari dua kelompok sampel yang tidak berhubungan. Analisis yang dilakukan pada penelitian ini merupakan penelitian two-tail, dengan taraf signifikansi (LOS) sebesar .05.

\section{HASIL DAN PEMBAHASAN}

Hasil penelitian menunjukkan bahwa range tingkat stres kerja yang dialami oleh 84 responden adalah 1.27-3.60, dengan rata-rata $M=2.16$, dan $\mathrm{SD}=0.534$. Responden yang berada diatas rata-rata dari populasi responden dikatakan sebagai responden dengan tingkat stres kerja tinggi. Responden dengan tingkat stres kerja tinggi sebanyak 36 responden (42.86\% dari total responden). Responden dengan tingkat stres kerja rendah sebanyak 48 responden (57.14\% dari total responden). Dapat disimpulkan bahwa sebagian besar responden dari populasi responden mengalami stres tingkat rendah.

Secara umum, strategi coping stress yang paling banyak digunakan oleh 84 responden adalah religious-focused coping, rata-rata $M=4.07$ ( $\mathrm{SD}=.648$ ), diikuti dengan problem-focused coping, ratarata $M=3.53$ ( $\mathrm{SD}=.606$ ), dan strategi coping stress terakhir adalah emotion-focused coping, rata-rata $M=2.81$ ( $\mathrm{SD}=.537)$. Range penggunaan strategi religious-focused coping adalah 1-5, range penggunaan strategi problem-focused coping adalah 2-5, dan range penggunaan strategi emotionfocused coping adalah 1.67-2.42.

Hasil penelitian berikutnya merupakan uraian hubungan antara tingkat stres kerja responden dengan pemilihan strategi coping stress. Uraian hubungan tersebut dapat menjawab hipotesis penelitian ini. Hipotesis pertama $\left(\mathrm{H}_{1}\right)$ penelitian ini melihat hubungan positif antara tingkat stres kerja dengan penggunaan strategi emotion-focused coping. Analisis dengan menggunakan korelasi Pearson menunjukkan bahwa hubungan antara tingkat stres kerja rata-rata $(M=2.16, \mathrm{SD}=.534)$ dengan penggunaan strategi emotion-focused coping $(M=2.81, \mathrm{SD}=.537)$ adalah $r=0.365, n=84$, dan $p=$ 0.001 signifikan. Hal ini ditandai dengan terdapatnya hubungan positif antara tingkat stres kerja dengan penggunaan strategi emotion-focused coping. Diterimanya hipotesis pertama, menunjukkan ditolaknya hipotesis kedua.

Hasil penelitian berikutnya menunjukkan adanya hubungan negative antara tingkat stres kerja dan pemilihan strategi problem-focused coping, sebesar $r=-.414, n=84, \quad p=.000$. Selanjutnya, hasil penelitian menunjukkan tidak terdapat hubungan antara tingkat stres kerja dengan religiousfocused coping. Hal ini ditandai dengan nilai $r=-.172, n=84, p=.117$. Nilai $r$ ini mengindikasikan bahwa strategi ini selalu digunakan pada tingkat stres kerja manapun.

Analisa tambahan pada penelitian ini yaitu gambaran sumber stres kerja yang dirasakan karyawan, hubungan antara problem-focused coping dengan religious-focused coping, perbedaan tingkat stres kerja antara dua divisi di Adira Insurance, perbedaan penggunaan emotion-focused coping pada tiga divisi di Adira Insurance, serta perbedaan penggunaan emotion-focused coping antara responden dengan jenis kelamin pria dan wanita di Adira Insurance.

Berdasarkan kuesioner yang telah ditanggapi oleh responden, sumber stres yang paling dirasakan responden adalah sumber stres yang disebabkan oleh faktor tuntutan peran dengan rata-rata $M=1.73$ ( $\mathrm{SD}=.814)$. Sumber stres yang dirasakan responden selajutnya adalah faktor tuntutan tugas dengan rata-rata $M=1.63(\mathrm{SD}=.662)$ dan sumber stres terakhir yaitu faktor tuntutan interpersonal dengan rata-rata $M=1.26(\mathrm{SD}=.494)$.

Analisa tambahan berikutnya melihat hubungan yang terjadi antara problem-focused coping dengan religious-focused coping. Hasil yang diperoleh yaitu terdapat hubungan positif antara problemfocused coping dengan religious-focused coping, $r=0.353, n=84$, dan $p=0.001$ signifikan. 
Analisis tambahan selanjutnya berupa perbedaan tingkat stres kerja antar divisi di Adira Insurance. Analisis dengan menggunakan oneway ANOVA menemukan adanya perbedaan tingkat stres kerja yang signifikan berdasarkan divisi pekerjaan, $F(9,66)=2.585, \mathrm{p}=0.013$ signifikan. Perbedaan terletak antara para pekerja di Divisi Dealer, Leasing, and Agency $(M=1.78, S D=.40)$, dengan Divisi $I T(M=2.7, S D=.63), \mathrm{p}=.031$ signifikan.

Analisis tambahan selanjutnya berupa perbedaan penggunaan emotion-focused coping pada divisi di Adira Insurance. Analisis dengan menggunakan oneway ANOVA menemukan adanya perbedaan penggunaan emotion-focused coping yang signifikan berdasarkan divisi pekerjaan, $F(9,66)$ $=2.906, \mathrm{p}=0.006$ signifikan. Perbedaan terletak antara para pekerja di Divisi Dealer, Leasing, and Agency $(M=2.53, S D=.49)$, dengan Divisi Finance and Accounting $(M=3.33, S D=.20), \mathrm{p}=.009$ signifikan. Perbedaan penggunaan emotion-focused coping juga ditemukan antara para pekerja di Divisi Claim and Technical Operation $(M=2.25, S D=.38)$, dengan Divisi Finance and Accounting $(M=3.33, S D=.20), \mathrm{p}=.034$ signifikan.

Analisa tambahan yang terakhir berupa perbedaan penggunaan emotion-focused coping antara responden dengan jenis kelamin pria dan wanita di Adira Insurance. Peneliti membandingkan dua variabel ini dengan menggunakan independent samples t-test. Hasil yang diperoleh yaitu terdapat perbedaan yang signifikan pada pemilihan emotion-focused coping antara responden dengan jenis kelamin pria $(\mathrm{M}=2.55, \mathrm{SD}=0.43)$ dan wanita $(\mathrm{M}=2.91, \mathrm{SD}=0.55) ; \mathrm{t}(77)=-3.09, \mathrm{p}=0.003$ signifikan.

\section{Diskusi}

Hasil analisis menunjukkan bahwa terdapat hubungan positif antara tingkat stres kerja dengan penggunaan strategi emotion-focused coping, artinya semakin tinggi tingkat stres kerja, maka semakin sering penggunaan emotion-focused coping. Hal ini ditandai dengan meningkatnya nilai penggunaan emotion-focused coping, sejalan dengan semakin tinggi tingkat stres kerja yang dialami karyawan. Hasil ini didukung secara teoritis, menurut Lazarus dan Folkman (1984), emotion-focused coping dilakukan individu jika ia menghadapi situasi yang mengancam atau berada pada tingkat stres kerja yang tinggi.

Hasil penelitian menemukan bahwa strategi coping stress yang paling banyak digunakan responden adalah religious-focused coping. Hal ini mendukung hasil disertasi Dahlan (dalam Primaldhi, 2006) yang menemukan bahwa responden Indonesia selalu menggunakan religious-focused coping. Meskipun religious-focused coping merupakan strategi coping stress yang paling banyak digunakan oleh responden, namun coping stress ini tidak berhubungan dengan tingkat stres kerja yang dirasakan responden. Hasil analisis menunjukkan bahwa walaupun ketiga strategi coping stress digunakan oleh responden, hanya emotion-focused coping yang mempunyai hubungan positif dengan tingkat stres kerja.

Analisis tambahan menunjukkan adanya hubungan positif antara religious-focused coping dengan problem-focused coping, namun tidak menemukan hubungan antara religious-focused coping dengan emotion-focused coping. Hal ini sejalan dengan hasil penelitian Primaldhi (2006) dan mendukung sebagian dari hasil penelitian Dahlan (dalam Primaldhi, 2006) yang menemukan adanya hubungan antara religious-focused coping dengan strategi problem-focused coping, dan emotionfocused coping, pada sampel Indonesia (dalam Primaldhi, 2006). Informasi tambahan mengenai religious-focused coping sangat penting karena coping stress tersebut masih baru di Indonesia.

Analisis berikutnya melihat gambaran sumber stres kerja yang paling dirasakan responden. Hasil penelitian menemukan sumber stres kerja yang paling dirasakan responden yaitu tuntutan peran. Robbins \& Judge (2007) mengartikan tuntutan peran sebagai salah stau sumber stres dari faktor 
organisasi yang menempatkan karyawan pada peran tertentu di perusahaan, namun dapat menyebabkan konflik tertentu pada peran tersebut, seperti ketidakcocokkan dengan harapan karyawan yang menjalankan peran, kebingungan peran atau tidak diberitahu dengan pasti peran yang dijalaninya dalam perusahaan tersebut. Tidak dilakukan generalisasi pada data ini, hal ini berarti tuntutan tugas bukan merupakan faktor sumber stres yang dirasakan semua karyawan di kantor pusat Adira Insurance. Namun hal ini dapat menjadi masukkan bagi Adira Insurance dalam hal yang berhubungan dengan pemberian atau pembagian peran karyawan.

Analisa tambahan yang selanjutnya dilakukan untuk melihat apakah ada perbedaan tingkat stres kerja yang dirasakan oleh responden berdasarkan faktor demografis, yaitu divisi pekerjaan. Peneliti melihat perbedaan tingkat stres kerja yang signifikan antara responden pada Divisi Dealer, Leasing, and Agency dan Divisi IT Hasil penelitian ini sejalan dengan teori stres Lazarus \& Folkman (1984) yang menyatakan bahwa stres merupakan hasil dari interaksi individu dengan lingkungan. Berdasarkan pernyataan dan temuan diatas, dapat disimpulkan bahwa lingkungan.turut berpengaruh pada tingkat stres kerja yang dirasakan responden.

Setelah menemukan perbedaan tingkat stres kerja yang signifikan antara divisi di Adira Insurance, peneliti juga menemukan perbedaan penggunaan emotion-focused coping yang signifikan antara divisi di Adira Insurance. Peneliti menemukan perbedaan penggunaan emotion-focused coping yang signifikan antara Divisi Finance and Accounting dengan Divisi Dealer, Leasing, and Agency dan Divisi Claim and Technical Operation. Temuan ini juga mendukung teori stres Lazarus \& Folkman (1984) yang menyatakan bahwa stres merupakan hasil dari interaksi individu dengan lingkungan.

Analisis terakhir dari hasil penelitian ini yaitu perbedaan penggunaan emotion-focused coping yang dilihat dari responden dengan jenis kelamin pria dan wanita. Terdapat perbedaan penggunaan emotion-focused coping yang signifikan antara responden dengan jenis kelamin pria dan wanita. Responden dengan jenis kelamin wanita lebih menggunakan emotion-focused coping daripada responden dengan jenis kelamin pria. Hasil penelitian ini sejalan dengan penelitian Patton, Wendy, Goddard \& Richard (2006) yang menemukan perbedaan penggunaan strategi coping stress antara pria dan wanita. Penelitian Ptacek dan Skues \& Kirby melaporkan bahwa karyawan wanita lebih menggunakan emotion-focused coping dibandingkan pria dalam menghadapi stres (dalam Patton, Wendy, Goddard dan Richard, 2006). Hasil peneltian mengenai penggunaan strategi coping stress ini kiranya dapat menjadi informasi yang berguna bagi Adira Insurance apabila akan melakukan program penanggulangan stres kerja karyawan atau pengembangan EAP (Employee Assistance Program).

\section{PENUTUP}

Peneliti memiliki beberapa saran yang ditujukan pada penelitian selanjutnya dan perusahaan. Berikut ini akan dibahas lebih lanjut mengenai saran yang diberikan peneliti. Saran untuk penelitian selanjutnya sebaiknya menggunakan parameter sampel untuk memperluas generalisasi hasil penelitian. Generalisasi hasil penelitian dapat memberikan gambaran yang lebih luas mengenai keadaan populasi. Saran kedua bagi penelitian selanjutnya mengenai hubungan tingkat stres kerja dengan faktor-faktor lain. Penelitian selanjutnya dapat menggali lebih dalam mengenai hubungan tingkat stres kerja dengan faktor sumber stres kerja yang lain, seperti faktor lingkungan eksternal (kondisi fisik ruang kerja, ketidakpastian politik suatu negara, perubahan siklus bisnis yang menciptakan ketidakpastian ekonomi, dan inovasi teknologi yang pesat) atau faktor individu (masalah keluarga, perceraian, masalah dengan anak, masalah ekonomi keluarga dan kepribadian karyawan).

Penelitian selanjutnya sebaiknya dapat melihat dampak stres kerja jangka panjang, jika didapatkan gambaran dampak stres jangka panjang dari suatu perusahaan, penelitian tersebut diharapkan mampu menggambarkan kerugian finansial pada suatu perusahaan di Indonesia yang 
diakibatkan stres yang dirasakan karyawan. Dengan adanya gambaran kerugian finansial tersebut, diharapkan perusahaan menganggap stres kerja sebagai hal yang penting. Sehingga, perusahaan tidak hanya menomorsatukan kesehatan fisik karyawan, tetapi juga kesejahteraan mental karyawan. Hasil penelitian ini tidak dapat digeneralisasikan dengan populasi. Penelitian ini menemukan sebanyak 36 karyawan (42.86 \% dari total responden) merasakan stres yang lebih tinggi daripada karyawan lain. Saran bagi karyawan yang mengalami stres kerja dalam waktu yang berkepanjangan dan merasa terganggu, karyawan tersebut dapat berkonsultasi pada psikolog. Saran jangka pendek bagi perusahaan dapat dipikirkan pelayanan EAP (Employee Assistance Program) agar stres yag terjadi tidak menggangu kinerja. Untuk jangka menengah dan jangka panjang maka perlu diteliti lebih spesifik halhal yang menjadi sumber stres utama. Melalui studi ini maka akan dapat disusun strategi yang lebih tepat untuk tetap mempertahankan tingkat kierja sekaligus menekan stres yang mengganggu atau distress.

\section{DAFTAR PUSTAKA}

Atkinson, R. L., Atkinson, R. C., \& Hilgard, E. R. (1991). Pengantar psikologi: Jilid 2 (8th ed.). Jakarta: Erlangga.

Bass, B. M., \& Barret, G. V. (1981). People, work, and organization (2nd ed.). USA: Allyn and Bacon.

Dubrin, A. J. (1990). Effective business psychology (3rd ed.). USA: Prentice-Hall International.

Knox, C. (2009). Tackling stress in workplace. Diakses pada 8 Juni 2010, dari http://findarticles.com/p/articles/mi_6783/is_2009_Nov_5/ai_n42026534/

Lazarus, R. S., \& Folkman, S. F. (1984). Stress, appraisal, and coping. New York: Springer Publishing.

Lilienfeld, S., Lynn, S. J., Namy, L. L., \& Woolf, N. J. (2009). Pscyhology: from inquiry to understanding. USA: Pearson Education.

Munandar, A. S. (2001). Psikologi Industri dan Organisasi, Jakarta: Universitas Indonesia Press.

Patton, W. A., \& Goddard, R. (2006). Coping with stress in the Australian job network: Gender differences. Journal of Employment Counseling.

Pergament, K. I. (1997). Psychology of Religion and Coping: Theory, Research, Practice, NY: The Guilford Press.

Priyatno, D. (2008). Mandiri Belajar SPSS (Statistical Product and Service Solution): untuk Analisa Data \& Uji Statistik. Yogyakarta: MediaKom.

Primaldhi, A. (2006). Hubungan antara trait kepribadian neuroticism, strategi coping, dan stres kerja. Jurnal Psikologi Sosial, 14, 205-217.

Purnomo, S. (2006). Hubungan masa kerja dengan stres kerja pada pustakawan perpustakaan Universitas Gadjah Mada Yogyakarta. Jurnal Berkala Ilmu Perpustakaan dan Informasi, 3, 44-58. 
Robbins, S. P., \& Judge, T. A. (2007). Organizational behavior (12th ed.). New Jersey: Pearson Education.

Ross, R. R., \& Altmaier, E. (1994). Intervention in occupational stress. Thousand Oaks, CA: Sage Publications.

Woollard, S. (2009). Stress is a bigger problem than 1970s strikes. Diakses pada tanggal 10 Desember 2010 dari $\mathrm{http}: / / \mathrm{www} \cdot$ bnet.com/blog/sterling-performance/stress-is-a-bigger-problem-than1970s-strikes/2394

Woolston, C. (2009). Work \& Health: Job Stress. Dibuka pada tanggal 10 Desember 2010 dari http://www.cvshealthresources.com/topic/safework 